\title{
The Accession Response of Local Rice and Ameliorant of Palm Rung Ashon the Growth and the Result of Padi (Oryza sativa L.) in Peat Soil
}

\author{
Safrida $^{1}$, Efendi $^{1}$, Teti Arabia ${ }^{1}$ \\ ${ }^{1}$ Agrotechnology Program, Agriculture Faculty, Syiah Kuala University, Banda Aceh, Indonesia
}

\begin{abstract}
This study aims to investigate the accession response of local rice, the influence of the ameliorant palm ash and the significant or not significant interaction of two factors at planting on peat soil. This study is arranged in Split Plot Plan with 2 treatments and 9 groups which consist of nine accessions of local paddy that is: Sanbei, Bo Santeut, Pineung lango, Ramos mirah, Pandrah, Cut Krusek, Boh Sireutoh, Inpago 5, IR-36. The ameliorant factors of palm oil ash consist of: 0 ton ha ${ }^{-1}$ and 15 ton ha ${ }^{-1}\left(3,38 \mathrm{~kg} \mathrm{plot}^{-1}\right)$. The study results show that the accession highly affects significantly on plant height, number of young plant age of 45, 60, 75 and 90 HST, flower age, number of productive young plants, panicle length, panicle weight, percentage of filled grain, the percentage of empty grains, 1000 grain weight, per plot grain weight, yield potential, affected significantly on the number of young plant age of $30 \mathrm{HST}$ and lower part of biomass but has no affect significantly on the upper part of biomass. Ameliorant affects significantly on plant height and the number of young plant age 30 HST, affect significantly on the plant height at age 60, 75 and 90 HST, the young plant age of 90 HST, the flower age and the number of productive young plant, 1000 grains weight, the upper part of biomass and the lower part of biomass. Ameliorant has no effect significantly on the plant height at the age of 45, 90 HST, panicle length, panicle weight, the percentage of filled grains, percentage of empty grains, per plot grain weight, production per hectare.
\end{abstract}

Keywords:- rice accessions; amelioran of palm rungs ash ; agriculture

\section{INTRODUCTION}

Paddy or rice (Oryza sativa L.) is the dominant staple food consumed by most Indonesians, but the availability of rice is still low to meet the needs of the Indonesian population. The transfer of wet soil to non-rice field is one of the causes of lack of rice fields in Indonesia. This condition continues in line with the population growth, industrial activities, transportation and natural disasters so that it is seen necessary to empower the marginal soils that have not been optimally productive. One of the soils that which is not yet optimal in its utilization is peat soil (Utama and Harjoko, 2009). Viewing from the soil physicochemical nature, the most common problems found are due to low $\mathrm{pH}$, low base saturation, high cation exchange capacity, high $\mathrm{C} / \mathrm{N}$ ratio, and the availability of low macro and micro nutrient. Other inhibiting factors such as the presence of organic acids that are toxic, poor drainage which do not support the creation of sufficient nutrient supply for the plants. Thus, agricultural extensive efforts on the peat soil face various constraints (Zuraida, 2013). The efforts to increase peat soil productivity can be achieved by applying water management technology, amelioration and fertilizing as well as appropriate selection of commodities. According to Subiksa et al. (1995); Salampak (1999); And Mario (2002), lime, mineral soil, manure and burning ash can be applied to the peat soil as ameliorant material to increase the $\mathrm{pH}$ and soil bases. Palm rung ash can be used as an ameliorant type of peat soil because it has complete nutrients both macro and micro, able to increase the soil $\mathrm{pH}$ and has high base saturation where the content of the cation can neutralize the toxic compounds when the availability is sufficient (Sasli, 2011).

Several studies show that the provision of palm rung ash can increase the soil $\mathrm{pH}$ and has a significant effect on the increase in potassium levels (K-dd) (Panjaitan et al., 2003). The results of Sari research (2011) shows that the provision of palm ash has a significant effect on the availability of $\mathrm{Cu}, \mathrm{Zn}, \mathrm{Fe}$, and $\mathrm{Mn}$ nutrients on peat soil. Giving and increasing dosage of palm ash can also increase peat soil $\mathrm{pH}$.Aceh is a province which is very rich in the diversity of local rice varieties that need to be conserved and utilized for sustainable development. The accession of Aceh's local rice is still widely used by farmers in various districts of Aceh Province, but in relatively small numbers this is due to the widespread use of national superior varieties (Silitonga, 2008). The research results of Bakhtiar et al. (2011) show some of the results in the exploration of Aceh's local plasmanutfah rice on acid soil has been obtained 26 accessions such as Cut Krusek, Bo Santeut, Ramos Tihion, Sigupai, Cantek Wangi, Cantek Puteh, Rangan and others. 


\section{RESEARCH METHODS}

This research was conducted in experimental garden of Agricultural Faculty of Teuku Umar Meulaboh University of West Aceh Distrit, located at an altitude of $0.8 \mathrm{~m}$ above the sea level. The district of West Aceh includes a sub-tropical area, where the dry and rainy seasons are not much different. The rainfall levels are almost evenly distributed throughout the year, an average of 16 days/month. The type of the soil is peat soil. This research was conducted from January to August 2015. The laboratory research was conducted in the soil and plant laboratory of Agriculture Faculty of Syiah Kuala University. The research was arranged in Split Plot Design with 2 treatments and 9 groups, consist of 9 local rice accessions: Sambe, Bo Santeut, Pineung Lango, Ramos mirah, Pandrah, Cut Krusek, Boh Sirutoh, Inpago 5, IR-36. Ameliorant factor of palm rung ash consists of: 0 ton ha ${ }^{-1}$ dan 15 ton $\mathrm{ha}^{-1}\left(3,38 \mathrm{~kg} \mathrm{plot}^{-1}\right)$. The initial soil analysis were carried out on: C-organic, soil pH, Ntotal, P-available, K-available, exchangeable $\mathrm{Ca}, \mathrm{Mg}$ exchangeable, $\mathrm{Na}$ exchangeable, Cation Exchange Capacity, base saturation and moisture contents in the field capacity.

The seeds prior to sowing first they are sprouted in the oven for 3 days with a temperature of $30^{\circ} \mathrm{C}$. The planting is conducted 15 days after planting and 15 days after the application of ameliorant rung ash of palm with plant spacing $25 \times 25 \mathrm{~cm}$ with the number of seeds 1 stem per clump. The fertilizer used is the fertilizer of Urea $200 \mathrm{~kg} \mathrm{ha}^{-1}\left(45 \mathrm{~g} \mathrm{plot}^{-1}\right)$, SP-36 $150 \mathrm{~kg} \mathrm{ha}^{-1}\left(33,75 \mathrm{~g} \mathrm{plot}^{-1}\right)$ and KCl $100 \mathrm{~kg} \mathrm{ha}^{-1}\left(22,5 \mathrm{~g} \mathrm{plot}^{-1}\right)$. The fertilizer of SP-36 and $\mathrm{KCl}$ are given in scattered at the time of planting. Urea is given 3 stages (1/4 at the age 2 weeks after planting, $1 / 2$ at the age 6 weeks after planting and 1/4 at the age 10 weeks after planting). The provision of water is done when the dry season in accordance with the growth phase of rice crops. The weeding is conducted by considering the growing population of gulma. To prevent the orong-orong pest attack, the seeds are mixed with Furadan insecticide as much as $1 \mathrm{~g}$ for $1 \mathrm{~m}^{2}$ of caring. The parameters observed in this study were analysis of soil chemical properties and palm rung ash, plant height, number of productive young age, panicle length, panicle weight, percentage of filled grain, percentage of empty grain, the upper part of biomass, the root part of biomass, dry grain weight per plot and the potential outcomes.

\section{RESULTS AND DISCUSSION}

The results of the chemical analysis of peat soil used in this study are presented in Table 1 . The results show that the soil reacted acid with $\mathrm{pH} 4.13$, medium natrium, medium phosphor, low callium and very high $\mathrm{C}$ organic. Under such conditions, then for the rice cultivation on peat soil needs to be conducted of soil amelioration.

Table 1 The chemical analysis result of peat soil on Research soil

\begin{tabular}{|c|c|c|c|c|c|}
\hline No & Analysis Aspect & Unit & Value & Method & Criteria \\
\hline 1 & $\mathrm{pH}(\mathrm{H} 2 \mathrm{O})$ & - & -4.13 & Electrometric & Acid \\
\hline 2 & C-organic & $(\%)$ & 9.11 & Walkley \& Black & Very high \\
\hline 3 & N-total & $(\%)$ & 0.23 & Kjeldahl & Medium \\
\hline 4 & $\mathrm{C} / \mathrm{N}$ & - & 36.61 & - & Very High \\
\hline 5 & $\mathrm{P} 2 \mathrm{O} 5$ & (ppm) & 21.38 & Bray $\mathrm{P}$ & Medium \\
\hline 6 & Kation-Kation Basa & - & 16.07 & Flamephotometer & M edium \\
\hline & $\begin{array}{c}\text { - K-dd } 0.21 \\
\text { - Na-dd } 0.47 \\
\text { - Ca-dd } 5.18 \\
\text { - Mg-dd } 0.33\end{array}$ & $\begin{array}{l}\mathrm{me} / 100 \mathrm{~g} \\
\mathrm{me} / 100 \mathrm{~g} \\
\mathrm{me} / 100 \mathrm{~g} \\
\mathrm{me} / 100 \mathrm{~g}\end{array}$ & & & $\begin{array}{c}\text { Low } \\
\text { Medium Medium } \\
\text { Low }\end{array}$ \\
\hline 7 & $\mathrm{~KB}$ & $(\%)$ & 6.36 & Morgan & Very low \\
\hline 8 & CEC & $\mathrm{me} / 100 \mathrm{~g}$ & 97.20 & $\begin{array}{c}\text { Extract of NH40Ac } \\
\text { pH7 }\end{array}$ & Very high \\
\hline
\end{tabular}

The Analysis result of chemical ameliorant of palm rung ash (Table 2) shows that the pH of palm rung ash is very high, reaching $8.78, \mathrm{~N}, \mathrm{P}$ and $\mathrm{K}$ are also high compared to the elements level analyzed on the peat soil. Meanwhile, the palm rung ash according to Bangka (2010); Fauzi et al. (2002) contained 30-40\% $\mathrm{K}_{2} \mathrm{O}, 7 \%$ $\mathrm{P}_{2} \mathrm{O}_{5}, 9 \% \mathrm{CaO}$, and 3\% MgO. In addition, it contains micro nutrients $1200 \mathrm{ppm} \mathrm{Fe}, 100 \mathrm{ppm} \mathrm{Mn}, 400 \mathrm{ppm} \mathrm{Zn}$ dan $100 \mathrm{ppm} \mathrm{Cu}$. Meanwhile the research conducted by Hanibal et al. (2001) the palm rung ash contains nutrients, such as K-shaped compound of $\mathrm{K}_{2} \mathrm{O}(36,48 \%), \mathrm{P}_{2} \mathrm{O}_{5}(4,79 \%), \mathrm{MgO}(2,63 \%), \mathrm{CaO}(5,46 \%), \mathrm{N}-\mathrm{Total}$ (0,05\%), Mn (1230 ppm), Fe 3450 ppm, Cu 183 ppm, Br 125,43 ppm, Zn 28 ppm dan pH 11,9 - 12,0.

Table 2 Analysis result of chemical ameliorant of palm rung ash

\begin{tabular}{|c|c|c|c|}
\hline No & Analysis component & Elements Rate & Criteria \\
\hline 1 & pH of palm rung ash & 8.78 & High \\
\hline 2 & N-Total / N Total (Kjeldal) $(\%)$ & 1.12 & High \\
\hline 3 & C organic & 11.77 & High \\
\hline 4 & P2O5 total / Phosphate Total $(\%)$ & 1.52 & Low \\
\hline
\end{tabular}




\begin{tabular}{|c|c|c|c|}
\hline 5 & $\mathrm{~K} 2 \mathrm{O}$ total / Nitrogen Total (\%) & 2.95 & High \\
\hline
\end{tabular}

Note: Analysis result of chemical ameliorant of palm rung ash on laboratory soil of FP Unsyiah (2015)

In the soil of low $\mathrm{pH}$ or acidic, some micro elements are more widely available, especially in the form of cations such as $\mathrm{Fe}, \mathrm{Mn}, \mathrm{Zn}$ and $\mathrm{Cu}$. If the $\mathrm{pH}$ soil increases, then the ionic form of the cation is transformed into hydroxide/oxide that is not available for plants. The thing that should be considered in relation to plants is that each type of plant needs different micro elements so that if there is a little over dosage it would be toxic to plants.

\section{The accession response and Ameliorant of Palm rung ash}

The analysis results of the variance showed that the palm rung ash ameliorant and the accession there has been interaction which is very significant on the flowering age and panicle weight, grain weight per plot and the yield potential of rice plants (Appendix 22, 28, 35 and 37) as well as a significant interaction on the height of rice plants at the ages of 60, 75 and 90 HST (Appendix 6, 8 and 10). But there was no interaction of palm rung ash amelioran and accession to the height of the pant at the ages of 30 and 45 HST, the number of young plant at the age of 30, 45, 60, 75 and 90 HST, the number of productive young plants, panicle length, filled grains, empty grains, upper part of biomass and lower part of biomass (Appendix 2, 4, 12, 14, 16, 18, 20, 24, 26, 30, 32, 40 and 42).

\section{Flowering Age}

The results analysis of variance from the average age of the flowering plant as the result of palm rung ash ameliorant treatment and accession (Appendix 22) show that there is a significant interaction between palm rung ash ameliorant treatment and accession. The average age of flowering plants in each palm rung ash ameliorant treatment and accession can be seen in Table 3 .

Table 3 Average Flowering Age of Rice Plants on Various accessionsand dosage of palm rung ash ameliorant

\begin{tabular}{|l|c|c|c|}
\hline \multirow{2}{*}{ Accession } & \multicolumn{2}{c|}{$\begin{array}{c}\text { Palm rung ash ameliorant } \\
\text { (ton } \mathbf{~ h a}^{-\mathbf{1}} \text { ) }\end{array}$} & \multirow{2}{*}{ BNT $_{\mathbf{0 , 0 5}}$} \\
\cline { 2 - 4 } & $\mathbf{0}$ & $\mathbf{1 5}$ & \\
\hline Sanbei & $81.67 \mathrm{bA}$ & $83.33 \mathrm{cA}$ & \\
\hline Bo Santeut & $97.67 \mathrm{cA}$ & $97.00 \mathrm{cA}$ & \\
\hline Pineung Lago & $97.67 \mathrm{cA}$ & $97.33 \mathrm{cA}$ & \\
\hline Ramos Mirah & $97.33 \mathrm{cA}$ & $98.00 \mathrm{cdA}$ & \\
\hline Pandrah & $75.00 \mathrm{aA}$ & $68.00 \mathrm{bA}$ & \\
\hline Cut Krusek & $98.00 \mathrm{cA}$ & $90.00 \mathrm{dA}$ & \\
\hline Boh Sireutoh & $97.00 \mathrm{cA}$ & $98.33 \mathrm{cdA}$ & \\
\hline Inpago 5 & $75.00 \mathrm{aA}$ & $63.33 \mathrm{aB}$ & \\
\hline IR-36 & $73.33 \mathrm{aA}$ & $65.00 \mathrm{aA}$ & \\
\hline Average & & & \\
\hline
\end{tabular}

Note: The number in the line followed by the same capital letter and number in the column followed by the same lowercase letter show there is no significant difference based on $\mathrm{BNT}_{0,05}$

The interaction between the palm rung ash ameliorant and the rice varieties affects the diversity of flowering age. Setyamidjaja (1986) states that the nutrient balance in the soil is an important factor for the metabolism smoothness that related closely to the growth and the production of the resulting plants. Saliban et al. (2014) say that crop production is influenced by metabolic processes in rice plants supported by the availability of nutrients in the soil such as potassium and sodium. Palm rung ash ameliorant has a good effect on the growth of generative plants and nutrients available on the peat soil especially the element of sodium which is very essential in accelerating the flowering age (Sugiyanto, 2007).

Lingga and Marsono (1994) also suggested if the nutrients needed by plants are available in the sufficient quantities, then the metabolic outcomes such as bio molecular synthesis will increase. This causes cell division, elongation and maturation of the cell becomes more perfect and faster, so that the increase in the volume and weight is getting faster that eventually the plant growth will get better.

\section{Panicle Weight}

The analysis result of the variance of the average panicle weight caused by the palm rung ash ameliorant and accession (Appendix 28) indicates that there is a significant interaction between the palm rung ash ameliorant and the rice accession. The average weight of each panicle of the palm rung ash ameliorant treatment and the accession can be seen in Table 4 .

Table 4 shows that the average weight of panicle on Inpago 5 variety with 15 ton ha ${ }^{-1}$ ameliorant treatment resulted in the highest panicle weight compared with the 0 ton ha ${ }^{-1}$. ameliorant treatment. The highest 
productive panicle weight on this variety reached $130.67 \mathrm{~g}$, while the treatment of 0 ton $\mathrm{ha}^{-1}$ control resulted the lowest amount of panicle weight $58.15 \mathrm{~g}$. The rice plant of Pandrah variety produces the highest panicle weight reached $123.22 \mathrm{~g}$, while on the treatment of 0 ton ha ${ }^{-1}$ only produces $78.57 \mathrm{~g}$.

Table 4 The average panicle weight of rice plants in various accessionsand dosage of palm rung ash ameliorant

\begin{tabular}{|c|c|c|c|}
\hline \multirow[t]{2}{*}{ Accession } & \multicolumn{2}{|c|}{$\begin{array}{c}\text { Palm Rung Ash Ameliorant } \\
\left.\text { (ton } \mathrm{ha}^{-1}\right)\end{array}$} & \multirow[t]{2}{*}{$\mathbf{B N T}_{\mathbf{0}, 05}$} \\
\hline & 0 & 15 & \\
\hline Sanbei & $28.88 \mathrm{aA}$ & $26.82 \mathrm{aA}$ & \multirow{9}{*}{26.23} \\
\hline Bo Santeut & $28.08 \mathrm{aA}$ & $23.35 \mathrm{aA}$ & \\
\hline Pineung Lago & $30.71 \mathrm{aA}$ & $24.61 \mathrm{aA}$ & \\
\hline Ramos Mirah & $45.96 \mathrm{aA}$ & $82.24 \mathrm{bB}$ & \\
\hline Pandrah & $78.57 \mathrm{aA}$ & $123.22 \mathrm{cB}$ & \\
\hline Cut Krusek & $40.37 \mathrm{aA}$ & $47.31 \mathrm{aA}$ & \\
\hline Boh Sireutoh & $44.55 \mathrm{abA}$ & $45.15 \mathrm{aA}$ & \\
\hline Inpago 5 & $58.15 \mathrm{aA}$ & $130.67 \mathrm{cB}$ & \\
\hline IR-36 & $43.41 \mathrm{aA}$ & $104.06 \mathrm{bcB}$ & \\
\hline Average & & & \\
\hline
\end{tabular}

Description: The numbers in lines followed by the same capital letters and the numbers in columns followed by the same lowercase letters show no significant difference based on $\mathrm{BNT}_{0,05}$

The IR-36 variety with 15 ton $\mathrm{ha}^{-1}$ of ameliorant treatment resulted the highest panicle weight compared with the treatment of 0 ton $\mathrm{ha}^{-1}$. The highest panicle weight in this variety reached $104.06 \mathrm{~g}$, whereas on the treatment of 0 ton $\mathrm{ha}^{-1}$ resulted a panicle weight of $43.41 \mathrm{~g}$. The rice of Ramos Mirah variety produces the highest panicle weight that reaches $82.24 \mathrm{~g}$ and the lowest produces only $45.96 \mathrm{~g}$. The interaction between palm rung ash ameliorant and the rice varieties affect the weight of panicles. Setyamidjaja (1986) states that the nutrient balance in the soil is an important factor for the metabolism smoothness that related closely to the growth and the production of the resulting plants. Saliban et al. (2014) say that crop production is influenced by metabolic processes in rice plants supported by the availability of nutrients in the soil such as potassium and sodium. Palm rung ash ameliorant has a good effect on the growth of generative plants and nutrients available on the peat soil especially the element of sodium which is very essential in accelerating the number of productive young plants (Sugiyanto, 2007).Lingga and Marsono (1994) also suggested if the nutrients needed by plants are available in the sufficient quantities, then the metabolic outcomes such as bio molecular synthesis will increase. This causes cell division, elongation and maturation of the cell becomes more perfect and faster, so that the increase in the volume and weight is getting faster that eventually the plant growth will get better.

The weight of Grain Plot $^{-1}$

The analysis results from variance of the average weight of grain plot $^{-1}$ resulted the palm rung ash ameliorant and the accession (Appendix 36) show that there is a very significant interaction between the amber ash bare palm and rice accession. The average weight of the grains plot-1 on each palm rung ash ameliorant treatment and the accession can be seen in Table 5 .

Table 5. the average weight of grain plot-1 of rice plants in various accessions and dosages of palm rung ash ameliorant

\begin{tabular}{|l|c|c|}
\hline \multirow{2}{*}{ Accession } & \multicolumn{2}{c|}{$\begin{array}{c}\text { Palm Rung Ash Ameliorant } \\
\left.\text { (ton } \text { ha }^{-1}\right)\end{array}$} \\
\cline { 2 - 3 } & 0 & BNT $_{\mathbf{0}, 05}$ \\
\hline Sanbei & $0.49 \mathrm{aA}$ & $0.43 \mathrm{aA}$ \\
\hline Bo Santeut & $0.48 \mathrm{aA}$ & $0.36 \mathrm{aA}$ \\
\hline Pineung Lago & $0.45 \mathrm{aA}$ & $0.35 \mathrm{aA}$ \\
\hline Ramos Mirah & $0.84 \mathrm{aA}$ & $1.31 \mathrm{bA}$ \\
\hline Pandrah & $1.61 \mathrm{aA}$ & $2.77 \mathrm{~dB}$ \\
\hline Cut Krusek & $0.69 \mathrm{aA}$ & $0.72 \mathrm{abA}$ \\
\hline Boh Sireutoh & $0.74 \mathrm{aA}$ & $0.80 \mathrm{ab} \mathrm{A}$ \\
\hline Inpago 5 & $0.88 \mathrm{aA}$ & $1.99 \mathrm{cB}$ \\
\hline IR-36 & $0.71 \mathrm{aA}$ & $1.92 \mathrm{cB}$ \\
\hline \multicolumn{1}{|c|}{ Average } & & \\
\hline
\end{tabular}

Description: The numbers in lines followed by the same capital letters and numbers in columns followed by the same lowercase letters show no significant difference based on $\mathrm{BNT}_{0,05}$ Table 5 shows that the treatment of palm rung ash ameliorant was able to increase the weight of plot $^{-1}$ grains in Pandrah variety that ranged from 1.61$2.77 \mathrm{~g}$, Inpago 5 ranged from $0.88-1.99 \mathrm{~g}$ meanwhile IR-36 ranged from $0.71-1.92 \mathrm{~g}$. The increase of plot-1 
grain weight is due to the dosage of palm rung ash ameliorant provided was sufficient to meet the nutrient needs either macro or micro nutrient crops. The treatment of palm rung ash can improve the $\mathrm{pH}$ of peat soil which is ideal for the growth and the production of rice crops. The ideal $\mathrm{pH}$ of soil will improve the status fertility of the soil.In palm rung ash ameliorant the $\mathrm{pH}$ and elements of Sodium, Phosphor and Potassium play roles in plant growth. Handayani (2015) states the element of Phosphor affects the growth and yield of plants, where Phosphor serves in breaking down the carbohydrates into energy in metabolism process. The reaction of micro nutrients in the soil on each soil is different. On soils with low $\mathrm{pH}$ or acidic, some micro elements are more widely available, especially in the form of cations, such as $\mathrm{Fe}, \mathrm{Mn}, \mathrm{Zn}$ and $\mathrm{Cu}$. If the $\mathrm{pH}$ of soil rises, the ionic form of the cation becomes hydroxide/oxide that is not available to the plant. The nutrient elements of $\mathrm{Cu}, \mathrm{Zn}, \mathrm{Fe}$ and $\mathrm{Mn}$ also determine the weight of plot-1 paddy rice because according to Hardjowigeno (2001) Zn plays a role in maturation the seeds and is a catalyst for protein formation, Fe plays a role in chlorophyll formation and is the enzyme and protein, $\mathrm{Cu}$ plays a role in carbohydrates and proteins metabolism while Mn plays a role in the photosynthesis process. According to Chan and Suwandi (1985), the most dominant macro elements found in palm rung ash are potassium and magnesium, while the micro elements are manganese and boron.

\section{Potential Results}

The analysis result of variance from the average of yield potentials due to the treatment of palm rung ash ameliorant and varieties (Appendix 38) shows that there is a very significant interaction between palm rung ash ameliorant and the rice varieties. The average weight of yield potential on each treatment of palm rung ash ameliorant and varieties can be seen in Table 6 .

Table 6. Average Potential of Rice plant in Various Varieties andDosage of palm rung ash ameliorant

\begin{tabular}{|l|c|c|c|}
\hline \multirow{2}{*}{ Accession } & \multicolumn{2}{c|}{$\begin{array}{c}\text { Palm Rung Ash Ameliorant } \\
\text { (ton ha-1 }\end{array}$} & \multirow{2}{*}{ BNT $_{\mathbf{0}, 05}$} \\
\cline { 2 - 3 } & 0 & 15 \\
\hline Sanbei & $2.17 \mathrm{aA}$ & $1.92 \mathrm{aA}$ \\
\hline Bo Santeut & $2.13 \mathrm{aA}$ & $1.61 \mathrm{aA}$ \\
\hline Pineung Lango & $1.99 \mathrm{aA}$ & $1.55 \mathrm{aA}$ \\
\hline Ramos Mirah & $3.72 \mathrm{aA}$ & $5.85 \mathrm{bA}$ \\
\hline Pandrah & $7.15 \mathrm{aA}$ & $12.31 \mathrm{~dB}$ \\
\hline Cut Krusek & $3.07 \mathrm{aA}$ & $3.18 \mathrm{abA}$ \\
\hline Boh Sireutoh & $3.27 \mathrm{aA}$ & $3.57 \mathrm{abA}$ \\
\hline Inpago 5 & $3.92 \mathrm{aA}$ & $8.86 \mathrm{cB}$ \\
\hline IR-36 & $3.17 \mathrm{aA}$ & $8.54 \mathrm{cB}$ & \\
\hline \multicolumn{1}{|c|}{ Average } & & \\
\hline
\end{tabular}

Description: The numbers in lines followed by the same capital letters and numbers in columns followed by the same lowercase letters show no significant difference based on $\mathrm{BNT}_{0,05}$ Table 6 shows that the palm rung ash ameliorant can increase rice yield potential in Pandrah variety that ranged from 7.15- 12.31 ton ha ${ }^{-1}$, Inpago 5 variety ranged from 3.92- 8.86 ton $\mathrm{ha}^{-1}$, variety IR-36 ranged 3.17 - 8.54 ton ha ${ }^{-1}$. The highest yield potential was obtained from the treatment of pandrah palm rung ash and Pandrah variety of 12.31 ton ha ${ }^{-1}$ while the lowest yield potential was obtained at the ameliorant treatment of 0 ton $\mathrm{ha}^{-1}$ that is Pineung Lango variety of 1.99 ton $\mathrm{ha}^{-1}$. The differences in potential yields are closely related to the ability of each variety to absorb the available nutrients, especially Phosphor. According to Warisno (1998) the absorption of different phosphor will cause photosynthesis which is produced by different rice plants so that the result of photosynthesis is trans-located for the requirement of filling the beans becomes different. The seeds will be perfectly formed if sufficient carbohydrate accumulation is available. The element of Phosphor is required for $75 \%$ of the rice plant during its generative period (Suardi and Haryono, 2002).

The increasing rice production cannot be separated from the use of varieties that suit the specific and the certain area location. The varieties play important roles in increasing the yield per unit area especially the rice (Rahayu and Harjoso, 2010). Plants can grow and develop well in extreme environments, the process occurs through genetic change as an effort to adaptation of the plant to the environement (Efendi et al., 2015).

In the ameliorant treatment of 0 ton $\mathrm{ha}^{-1}$, Pineung Lango variety produces little grain because of the variety of Pineung Lango which is sensitive to the peat soil. This is related to the absorption of the plants on micro nutrients are also low. The low weight of grain relates to the number of grains containing low and high percentage of the empty grain. This shows that each variety has adaptation power to the condition of peat soil environment with a palm rung ash ameliorant dosage 15 ton $\mathrm{ha}^{-1}$, because palm rung ash ameliorant contains micro and macro elements such as Potassium, Phosphor, Calcium and Magnesium. From the analysis of nutrient content of palm rung ash (Table 5) shows that palm rung ash contains potassium nutrient in the form of $\mathrm{K}^{2} \mathrm{O}$ $(2,95 \%), \mathrm{P}^{2} \mathrm{O}^{5}(1,52 \%), \mathrm{C}$-organic $(11,77), \mathrm{N}$-Total $(1,12)$ and $\mathrm{pH}(8,78)$. In accordance with the analysis result 
of palm rung ash nutrient by Hanibal et al. (2001) indicates that palm rung ash contains elements o $\mathrm{K}^{2} \mathrm{O}(36,48)$, $\mathrm{P}^{2} \mathrm{O}^{5}$ (4,790, $\mathrm{MgO}(2,63), \mathrm{CaO}(5,46), \mathrm{Mn}$ (1230 ppm), Fe (3450) ppm, Cu (183 ppm), Br (125,43 ppm), Zn (28 $\mathrm{ppm})$ and $\mathrm{pH}$ that ranged 11,9-12,0. Panjaitan et al., (1983) In his study, it is reported that palm rung ash has a high content of potassium nutrients. In accordance with the opinion of Chan and Suwandi (1985), the most dominant macro elements are found in palm rung ash are potassium and magnesium, while the micron elements are manganese and boron.The reaction of micro nutrients in the soil in each soil is different. In the soils with low $\mathrm{pH}$ or acidic, some micro elements are more widely available, especially in the form of cations, such as $\mathrm{Fe}$, $\mathrm{Mn}, \mathrm{Zn}$ and $\mathrm{Cu}$. When the soil $\mathrm{pH}$ rises, the ionic form of the cation becomes hydroxide/oxide that is not available to the plant. The thing tat needed to note in relation to the plants is that each type of plant is different its need for micro elements so that a little excess will be toxic to the plant.The element of potassium plays a role in supporting the growth of plants, which play a role in terms of photosynthesis of plants. The photosynthesis process of plant will produce carbohydrates, proteins and other organic compounds. The compounds produced are used in the process of cleavage and enlargement or differentiation of plant cells. The continual cleavage and prolongation of plant cells will spur the growth on shoots of plants and will eventually lead to the addition of plant height (Rohyanti et al., 2011).This study shows that with the ameliorant treatment on palm rung ash on the peat soils, it is able to increase the growth of the number of productive young plants in local rice plants because the nutrients contained in palm rung ash are immediately available for plants that have a positive effect on the chemical and biological nature of the peat soil. The palm rung ash is basically a potassium fertilizer and also as a liming agent to increase the $\mathrm{pH}$ with the application of peat and acid soil (Lahuddin, 2000) while the provision of fertilizer is one important element in adding nutrients to the plants. The provision of fertilizers in plants with appropriate dosages can increase availability of nutrient, increase soil microorganism activity and form soil aggregates so that it binds more nutrients (Hatta et al., 2010).Sutanto (2005) said that the soil's ability as a plant habitat to produce a harvested material is much determined by its fertility rate. Furthermore Setyamidjaja (1986) states that nutrient balance in the soil is an important factor for the smoothness of metabolism that is closely related to the growth of plants and the production of the plants resulted. The sufficiency of nutrients affects the growth and the production of plants, one of them is the number of productive young plants of rice crops.

\section{CONCLUSION}

Based on the research result, it can be concluded that the accession of paddy rice Pandrah has the best growth adaptation and production if it is planted on the peat soil and palm rung ash ameliorant dosage of 15 ton $\mathrm{Ha}^{-1}$ with the yield potential reached 12.31 ton $\mathrm{Ha}^{-1}$.

\section{REFERENCES}

[1] Bakhtiar, E., Kesumawati. T. Hidayat dan M. Rahmawati. 2011. Karakteristik Plasmanutfah Padi Lokal Aceh untuk Perakitan Varietas Adaptif pada Tanah Masam. Jurnal Agrista. Fakultas Pertanian Universitas Syiah Kuala. Banda Aceh

[2] Bangka, B. 2010. Pemanfatan Limbah Kelapa Sawit. Http://Budakbangka. Blogspot.com/2005/ pemanfatan-limbah-kelapa-sawit.

[3] Fauzi, Y., Y. E. Widyastuti., I. Satyawibawa dan R. Hartono. 2002. Kelapa Sawit : Budidaya, Pemanfaatan Hasil dan Limbah. Edisi Revisi, Penerbit Penebar Swadaya, Jakarta.

[4] Halim. A. 1987. Pengaruh Pencampuran Tanah Mineral dan Basa Tanah Gambut Pedalaman Kalimantan Tengan dalam Budidaya Tanaman Kedelai. Tesis S2 Institut Pertanian Bogor. 255 hlm.

[5] Hanibal, Sarman. dan Gusniwati. 2001. Pemanfaatan Abu Janjang Kelapa Sawit pada Lahan Kering dan Pengaruhnya Terhadap Pembentukan Nodula Akar, Pertumbuhan dan Hasil Tanaman Kedelai (Glaycine max). Fakultas Pertanian Universitas Jambi. Jambi.

[6] Krismawati, A. dan Z. Arifin. 2011. Stabilitas Hasil Beberapa Varietas Padi Lahan Sawah. Pengkajian dan Perkembangan Teknologi (2)

[7] Mario, M. D. 2002. Peningkatan Produktivitas dan Stabilitas Tanah Gambut dengan pemberian Tanah Mineral yang diperkaya oleh Bahan berkadar Besi Tinggi. Disertasi Program Pasca Sarjana, Institut Pertanian Bogor.

[8] Panjaitan, A. Sugijono. dan H. Sirait. 2003. Pengaruh Abu Janjang Sawit terhadap Kemasaman Tanah Podsolik, Regosol dan Aluvial. Bul. Balai Panel. Perkebunan Medan.

[9] Salampak. 1999. Peningkatan Produktivitas Tanah Gambut yang Disawahkan dengan pemberian Bahan Amelioran Tanah Mineral Berkadar Besi Tinggi.Disertasi S3. Program Pasca Sarjana Institut Pertanian Bogor.

[10] Sari, I. 2011. Studi Ketersediaan dan Serapan Unsur Hara Mikro serta Hasil beberapa Varietas Kedelai pada Tanah Gambut yang di Ameliorasi Abu Janjang Kelapa Sawit (artikel) Program Pasca Sarjana Universitas Andalas. Padang. 
[11] Sasli. 2011. Karakteristik Gambut dengan berbagai Bahan Amelioran dan Pengaruhnya terhadap Sifat Fisik dan Kimia Tanah guna mendukung Produktivitas Lahan Gambut. Jurnal Agrovigor.

[12] Subiksa, I. G. M., K. Nugroho Sholeh. dan P.G. Widjaja Adhil. 1995. The Effect of Ameliorants on the chemical Properties and productipity of peat soil. In Rieley and Page (Eds) Biodiversity and Sustainability of Tropical Peatland. Proceedings of the International Symposiumon Biodiversity, Environmental Importance and Sustainability of tropical peats and peatlands. Palangkaraya, $4-8$ September 1995.

[13] Utama, M. Z dan W. Harjoko. 2009. Pengujian Empat Varietas Padi Unggul Padi Sawah Gambut Bukaan Baru di Kabupaten Padang Pariaman. Jurnal Akta Agrosia Vol.12 No. 1 hlm 56-61 Jan - Jun 2009.

[14] Zuraida. 2013. Penggunaan berbagai Jenis Bahan Amelioran terhadap Sifat Kimia Bahan Tanah Gambut Hemik. Program Studi Agroteknologi. Fakultas Pertanian Universitas Syiah Kuala. Darussalam. Banda aceh 